Synthesis, part of a Special Feature on Telecoupling: A New Frontier for Global Sustainability

\title{
Biodiversity conservation in a telecoupled world
}

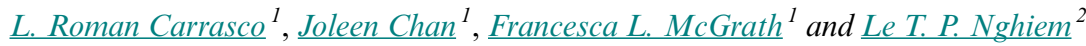

\begin{abstract}
The environmental and socioeconomic interactions between distant regions of the world ("telecoupling") are dramatically increasing. Telecoupling brings about new challenges and opportunities to biodiversity conservation that are of a larger magnitude and of a faster pace than ever observed before. Our understanding of the dynamics and leverage points of this telecoupled world is however limited. It is thus important to take stock of what we know and what we still need to know to formulate effective biodiversity conservation policies with telecoupling increasing. We identify the challenges and opportunities for biodiversity conservation brought about by the world's telecoupling in international trade and information by new technologies. Challenges are presented by the high demands for agricultural and wildlife products by high-income and emerging economies, putting pressure on land protection, management and incentive-based conservation interventions. Opportunities are brought about by the strength of telecoupled information flows that can generate strong pressure on multinationals and governments to adopt sustainable practices. Examples of these opportunities are zero-deforestation pledges and the increase in the number of certification schemes in key agricultural commodities. Conservation practitioners need to adopt a global perspective on telecoupling and focus on the new conservation opportunities represented by shaping the social norms of affluent consumers in emerging and high-income economies.
\end{abstract}

Key Words: certification; environmental footprint; globalization; illegal wildlife trade; leakage effects; teleconnections

\section{THE INCREASING ROLE OF TELECOUPLING ON CONSERVATION}

The past five decades have witnessed a proliferation in transportation, information, and communication technologies that have facilitated an increase in the complexity and number of distant interactions between countries (Anderson 2010). This increasing connectivity has enabled the global exchange of goods, information, capital, energy, and services between distant locations.

An indicator that epitomizes the connectivity of world systems is the rapid increase in volume of global agricultural goods exports (Fig. 1). These increased by $60 \%$ between 2000 and 2012 alone, together with a more complex transportation network that involves more trade between developing countries (Auboin et al. 2014). One of the main drivers of increasing trade is fast growing economies such as China and India that have seen, between 2000 and 2014, large increases in the importation of goods and services (average annual growth of $14.9 \%$ and $13.8 \%$, respectively, compared with the world average of 5.1\%; The World Bank 2015).

The implications of enhanced connectivity between countries have been successfully captured under a telecoupling framework, where telecoupling is an umbrella concept that refers to socioeconomic and environmental interactions over distances (Liu et al. 2013). Under this framework, the world is described as multiple coupled social-ecological systems that can interact remotely through exchanging flows of goods, energy, or information, and that could indirectly influence other spillover social-ecological systems (Liu et al. 2013). An example of this telecoupling is exhibited by the overseas loans of giant pandas (Ailuropoda melanoleuca) reared in nature reserves in China. Pandas are loaned to zoos overseas creating telecouplings on tourism, information dissemination, and trade of agricultural products that go, through spillover effects, far beyond the countries involved in the exchange of pandas (Liu et al. 2015a).
Fig. 1. Global trade in key agricultural commodities (FAO 2016) versus increases in the world population from 1980 to 2015 (UN 2015).

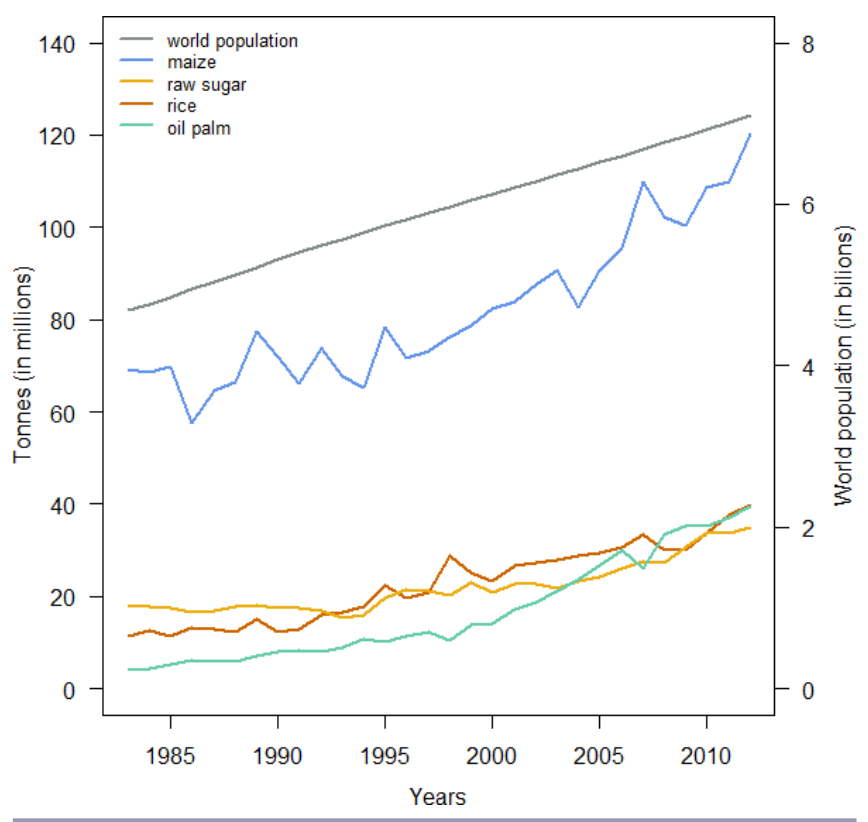

The complex network of connectivity in the world can lead to challenges and opportunities for biodiversity conservation that remain poorly understood, chiefly because of the prevalence of location and discipline specific studies as opposed to interdisciplinary global integrated studies (Liu et al. 2015b). This is highlighted by the scarcity of research that considers conservation interventions as an endogenous factor within the system in which the conservation intervention is applied, thus failing to identify unintended feedbacks (Larrosa et al. 2016), a key characteristic of telecoupling (Liu et al. 2013). Global

${ }^{1}$ Department of Biological Sciences, National University of Singapore, ${ }^{2}$ International Center for Tropical Agriculture (CIAT) - Asia Regional Office, Hanoi, Vietnam 
telecoupling cannot, however, be ignored given its current omnipresent role in conservation across space and time. A clear example of telecoupling affecting biodiversity is the introduction, either intentional or unintentional, of harmful nonindigenous species beyond their native range (Hulme 2009). For instance, the intentional introduction of the golden apple snail (Pomacea caniculata) from South America to Southeast Asia as a source of protein leads to large economic and environmental impacts in the region (Nghiem et al. 2013). Some other examples of telecoupling are how farmers are increasingly able to respond to global market signals, shaping land-use decisions and consumers' responses almost in real time (Galaz et al. 2015). A clear illustration is how the transformation from a socialist system to an economy based on market principles in Vietnam in the 1990s, together with land reforms, allowed rapid expansion of coffee production at the expense of forests. This resulted in an extra global supply of coffee and lower prices that led itself to livelihood instability among Mexican coffee farmers, causing migration to cities (Adger et al. 2009). Another example is how conservation interventions aimed at increasing reforestation in China and Vietnam had spillover effects via increased imports of timber from neighboring countries (Meyfroidt and Lambin 2009, Viña et al. 2016).

In this context of rapidly changing connections between distant social-ecological systems, conservation practitioners need to rapidly adapt to the increased telecoupling in the world. We focus on two of the main flows of exchange between countries that redefine the boundaries of biodiversity conservation: international trade (Lambin and Meyfroidt 2011) and information sharing via new technologies (Papworth et al. 2015). We aim to (i) develop an integrated telecoupling framework for these flows; (ii) identify the opportunities and challenges to biodiversity conservation brought about by the telecoupling of these flows; and (iii) identify key research priorities to understand how telecoupling can be better managed to avoid damage to biodiversity and boost the effectiveness of conservation interventions.

\section{A FRAMEWORK FOR BIODIVERSITY CONSERVATION IN A TELECOUPLED WORLD}

We build upon the existing telecoupling framework by Liu et al. (2013). This framework identifies coupled human and natural systems that interact in the distance. These systems are categorized between sending systems (e.g., Brazil exporting soy), receiving systems (e.g., China importing soy from Brazil), and spillover systems that receive indirect effects of the telecoupling (e.g., prices of soybean in the USA change as a result of the trade between Brazil and China). These systems interact through flows and contain agents that drive the telecoupling within each system. In our case, we identify importer and exporter systems that exchange the following: (1) trade flows (e.g., agricultural produce, wildlife products, and timber); (2) investments that involve financial agents like shareholders and multinational agribusinesses; and (3) information flows (Fig. 2A). We identify the emergence of spillover and feedback effects via modification of the telecoupled information flow. This modification can respond to growing environmental concern by agents in the importing country that could result from an environmental scandal (e.g., extinction of a charismatic species; Fig. 2B). This modification can lead to effects on the importer (e.g., consumers' boycott of products, trade bans, withdrawal of financial support) that can further cause feedback effects in trade and financial telecouplings (e.g., drop in share values of the agribusiness company or drop in price of the agricultural commodity; Fig. 2B). These feedback effects can generate further spillover effects through the engagement of other substitute agricultural commodities, new importers, and exporters. For instance, original Importer 1 may seek to import substitute products with better environmental performance (Exporter 2; Fig. 2B). Exporter 1 may also either adapt to the growing environmental concern of Importer 1 via certification schemes or via adaptation from agribusinesses (e.g., adoption of zero-deforestation pledges). Alternatively, Exporter 1 may seek alternative importers (Importer 2; Fig. 2B) with more relaxed environmental standards. These adaptations may lead to further price and investment feedback effects and may increase the supplying role of other agents within the exporting system (e.g., smallholders; Fig. 2B). Although the telecouplings considered can create pressures on conservation interventions by modulating agricultural opportunity costs and pressure for agricultural expansion, they can also create positive outcomes via enhanced environmental standards and adaptations to environmental concerns (Fig. 2B).

\section{TELECOUPLING THROUGH TRADE IN GLOBAL MARKETS}

International trade of agricultural products, biofuels, and other commodities has been rapidly growing (Fig. 1; OECD-FAO 2014). Telecoupled international trade has resulted in the redistribution of environmental impacts to other locations because of the direct and indirect use of natural resources of exporting countries (Srinivasan et al. 2008). Low-income exporting countries, in particular, bear the ecological debts of wealthier countries that have comparatively higher consumption rates (Srinivasan et al. 2008) and lose valuable ecosystem services through international trade that are only partly compensated by their gains in agricultural rents (Chang et al. 2016). International trade has indeed been shown to cause negative impacts on biodiversity among lowincome exporting countries (Lenzen et al. 2012). Increasing number of studies have further evaluated the strong implications of international trade on biodiversity (Chaudhary and Kastner 2016, Kitzes et al. 2016, Nishijima et al. 2016, Chaudhary et al. 2017, Moran and Kanemoto 2017). Similarly, international trade can generate biodiversity impacts through the introduction of harmful nonindigenous species (Hulme 2009), sometimes even directly associated to the act of trading such as invasive species transported through ship ballast water (Drake and Lodge 2004). One clear example of impacts on biodiversity due to telecoupled translocation of harmful nonindigenous species is the unintentional introduction of the brown tree snake (Boiga irregularis) to the island of Guam after World War II that led to the extirpation of most native vertebrates from the island (Wiles et al. 2003).

Growing trade does not only respond to the rising human population but also to a higher consumption per capita, related to affluence (Godfray et al. 2010). With increasing affluence, the demand for nutritionally richer food and protein products with comparatively higher environmental footprints is also growing (Tilman et al. 2011). Affluent consumers also show preferences for wildlife products together with demand for exotic pets that can contribute to the introduction of invasive species (Carrete and Tella 2008) and to the decline of endangered populations (Bush et al. 
Fig. 2. Conceptual framework describing the influence of telecoupling in investments, trade, and information on conservation strategies. (A) telecoupling of one importer and one exporter before growing environmental concern that modifies the information telecoupling. (B) Effects on telecouplings of a growing environmental concern or scandal (red dotted circle) spread by the telecoupled information systems. The scandal generates drops in telecoupled flows with adaptation from consumers, producers, and governments. Spillover effects to other exporters and importers through substitute products can further occur, creating opportunities and threats to conservation. PADDD: protected area downgrading, downsizing, and degazettment. Dotted lines indicated spillover effects. Red arrows indicate modification of the information telecoupling and subsequent direct effects.

A
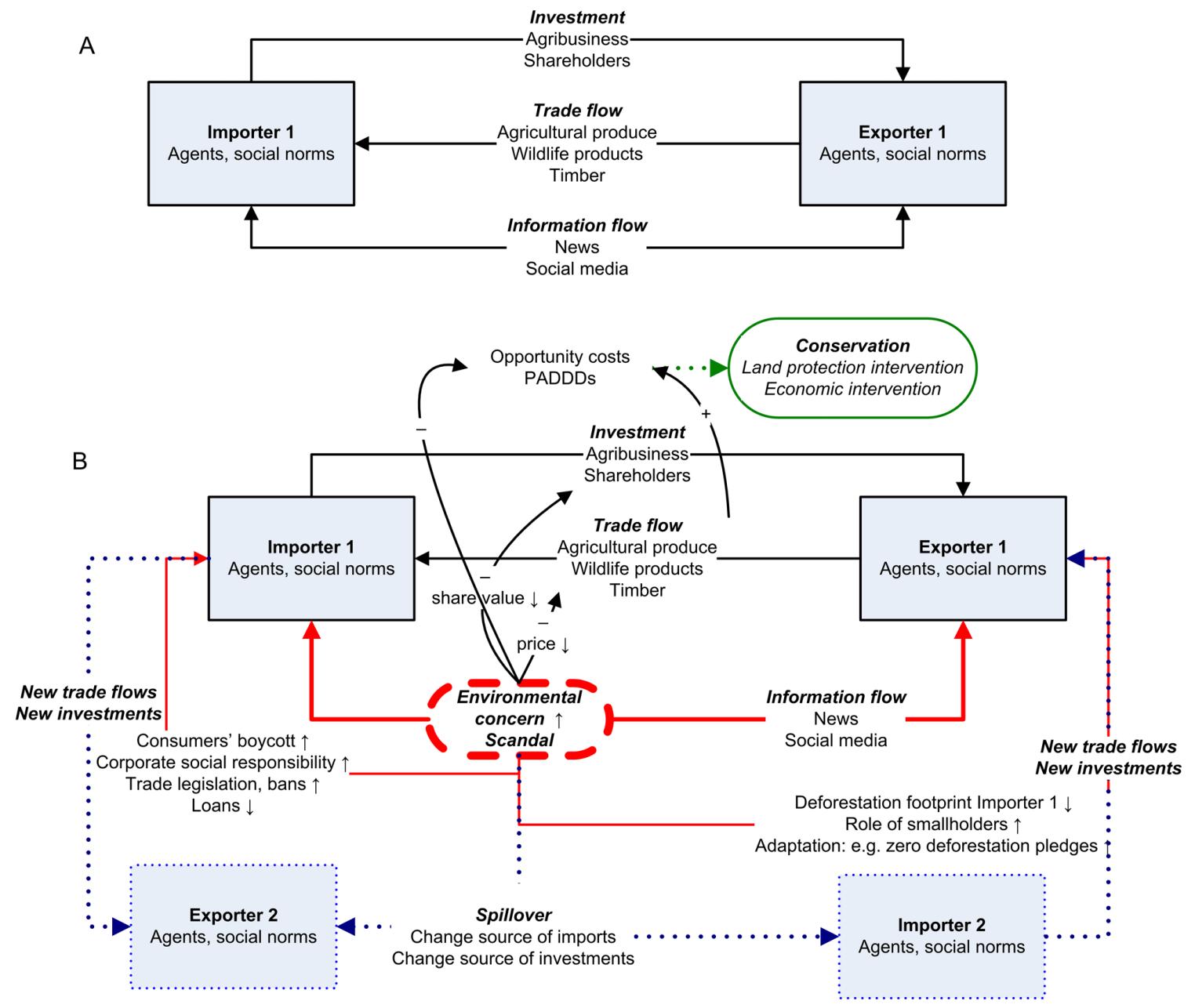

2014). For instance, the demand for animal parts such as rhino horn and tiger bone for traditional Chinese medicine is fueled by an increasingly affluent Chinese society (Graham-Rowe 2011). These particular preferences generate strong telecoupled legal and illegal wildlife trade flows that pose a challenge to the viability of wild populations. For instance, market prices in the pet trade were found to be a strong predictor of bird species declines in the wild in Indonesia (Harris et al. 2016). These trading dynamics are also replicated across agricultural and forestry commodities, typically between high-income importers and low-income exporters (e.g., Exporter 1 and Importer 1 in Fig. 2; Lenzen et al. 2012).

Although these telecoupled trade flows lead to habitat destruction and population declines that threaten biodiversity, they can also generate opportunities via opposing forces and spillovers (Fig. 2).
An example of this duality occurs in Brazil where a number of telecoupled processes such as gaining foot and mouth disease free status, devaluation of the local Brazilian currency, and bovine spongiform encephalopathy outbreaks in Europe, fueled beef exports and led to extensive expansion of cattle production and deforestation in the Amazon between 2002 and 2004 (Nepstad et al. 2006). The flip side of the coin is that deforestation has later decreased in the Amazon, partly because the soy and beef industries have become increasingly responsive to consumers' demands for better environmental and social performance from importers (Nepstad et al. 2006).

Similar dual opposing dynamics are observed in Southeast Asia with oil palm, one of the key drivers of deforestation in the region (Fitzherbert et al. 2008). Growing environmental concern from 
consumers and importers in regions like the European Union (e.g., Importer 1 in Fig. 2B) have motivated the creation of the Roundtable on Sustainable Palm Oil that issues certification (Certified Sustainable Palm Oil) for palm oil produced meeting environmental and social standards (Wilcove and Koh 2010). Certification as an adaptation to telecoupled growing environmental concerns can help reduce pressure on biodiversity and thus represents a fundamental opportunity to biodiversity conservation. Indeed, the certification of agricultural crops is growing rapidly and is strongly associated to crops that are heavily traded (Tayleur et al. 2016). For instance, 57\% of large multinational companies, including giants Nestle and Unilever, have committed to use only certified palm oil (WWF 2016). There may be, however, indirect links or spillover effects with alternative palm oil markets such as China and India (e.g., Importer 2 in Fig. 2), where pressure on producers' environmental performance is lower, leading to low demand for certified palm oil. Feedback effects could lead to increases in prices of certified palm oil or lower palm oil demand that could lead to an increase in demand for substitute products such as rapeseed oil produced in temperate regions (spillover effect on Importer 2), which could in turn potentially reduce pressure on tropical biodiversity (Carrasco et al. 2014). By contrast, this could also mean that lower palm oil prices incentivize demand from regions with low environmental concern, posing further threats to biodiversity. The framework is also transferable to the problem of invasive species. As an illustration, New Zealand (Exporter 1) and Australia (Importer 1) engage in apple trade that generates wealth to both countries but that can also be detrimental to the Australian environment through the potential introduction of fire blight (a disease caused by the bacterium Erwinia amylovora that affects plants from the Rosaceae family; Cook et al. 2011). As environmental concerns grow in Australia, a decision may be made to stop trade, which would imply that apples would be imported from other countries, affecting prices and land use practices in other spillover systems. The examples of palm oil and apple importations clearly illustrate the complexities of a super-connected telecoupled network of commodities, importers, and exporters (Fig. 2).

An added difficulty that makes trade telecoupling especially challenging for conservation is not only the complexity and the strength of the land-use signal but how rapid it is, making it difficult to trace responsibilities (Adger et al. 2009). The difficulty in tracing responsibilities stems from the disconnection between consuming and producing systems. An example of this disconnection is how international trade weakens the price signals that fisheries send to distant consumers, preventing global sustainable governance of fisheries (Crona et al. 2015). Increasing the traceability of responsibilities from producers to consumers is thus important because it presents a key opportunity for biodiversity conservation that merits further research (Table 1 shows key research priorities). This is especially so given that large multinational companies are remarkably sensitive to environmental scandals associated to their supply chain and willing to adopt better practices (Fig. 2B). Related to certification, a clear example of the power of trade telecoupling on achieving conservation goals are zero deforestation pledges motivated through corporate social responsibility. For instance, through the Consumer Goods Forum, over 400 multinational companies have committed to achieve zero net deforestation by 2020. Similarly, industry giants McDonald's, Unilever, Cargill, Mars, and key palm oil producing multinationals have pledged zero deforestation. These conservation opportunities are, however, not exempted of opposing forces represented by the governments of exporting countries. In the case of palm oil, for instance, the Indonesian government perceives zero deforestation pledges as incompatible with economic development and negative for smallholders (Pirard et al. 2015). An example is the 2014 Indonesia Palm Oil Pledge, a zero deforestation pact signed by major palm oil companies that was dissolved under the influence of the Indonesian government (Arshad and Fogarty 2016).

Table 1. Key research priorities to boost conservation in a telecoupled work.

Key Research Priorities

- Develop models that can predict spillover effects and feedbacks caused by telecoupled systems.

- Study the implications of market volatility from outside pressures on

farmers' decision making and it may affect their long-term production.

- Study ways to enhance the traceability of businesses impacts on the

environment by developing models that can link remote sensing of land use with companies and purchasing decisions.

- Investigate how green bonds can be used to fund conservation projects and how to assess and guarantee their efficacy.

- Study how certification in key agricultural commodities can be used to obtain effective conservation outcomes.

- Study which conservation actions can contribute more cost effectively to change social norms in affluent consumers driving demand of wildlife products and agricultural products and thus deforestation, for example, campaigns with celebrities, increasing visibility of harmful environmental actions, policy interventions, sanctions.

- Research into using the Internet and social media to mobilize and sustain public interest in conservation.

- Study how to best integrate conservation interventions aimed at influencing telecoupling forces with existing on-the-ground interventions at the landscape level.

\section{Global financial markets}

Another special case of telecoupling through global markets involves financial investment markets. The financial interconnectedness among countries through financial markets, banks, and investors can also exert strong influence on companies and financial actors' decisions worldwide. One source of pressure that encourages companies to have high environmental standards is the fact that a large proportion of financial assets are managed by governments at the national level, e.g. pension funds. These government assets may follow national and ethical principles and treaties such as the Convention of Biological Diversity (Galaz et al. 2015). Relatedly, it is noteworthy that 1400 signatories managing US\$59 trillion worth of financial assets signed the United Nations Principles for Responsible Investment (https:// www.unpri.org/about/the-six-principles). This pressure on companies has already materialized in tangible examples. For instance, Norway's sovereign-wealth fund eliminated four companies from its investment plan because they caused tropical deforestation in the establishment of oil palm plantations (Hovland 2015). Similarly, the Spanish bank Santander, under pressure from Greenpeace, stopped providing financial loans to a leading pulp and paper company following evidence of its contribution to deforestation in Indonesia (Butler 2015). In addition to exerting pressures, new financial tools like "green 
bonds," with a current market value of US\$37 billion, encourage and open an array of future opportunities to fund conservation (Galaz et al. 2015). These bonds offer tax exemptions for investments that produce environmental benefits like the development of contaminated sites. However, the use of green bonds for conservation and ways to evaluate their actual effectiveness remains poorly understood (Galaz et al. 2015) and should be a research priority (Table 1).

Telecoupling through financial markets can, conversely, also jeopardize biodiversity. For instance, the 1997 Asian financial crises led to policy changes that allowed rapid deforestation in Indonesia (Sunderlin 1999). Speculation in stock markets can also drive rapid fluctuations in global crop prices causing volatility. Price volatility in turn influences farmers' land use decisions, potentially impacting ecosystems as farmers may not see the point of investing in long-term sustainable agricultural practices (Rueda and Lambin 2013, Galaz et al. 2015). For example, to safeguard their livelihoods when coffee prices fell, some coffee farmers in Mexico converted cropland to pastures or sugarcane plantations and expanded plantations into forests (Eakin and Wehbe 2009). Understanding how market volatility may affect conservation remains a research challenge (Table 1).

\section{TELECOUPLING THROUGH INFORMATION}

Telecoupled information flows via new technologies like the Internet and social media also generate challenges and opportunities for biodiversity conservation. Among the challenges, the convenience of the Internet to advertise and sell goods coupled with the lack of stringent regulation of online shopping means that wildlife products can be sold over the Internet illegally without needing regulation from a third party (Alacs and Georges 2008). For instance, about 10\% of Greek endemic plant species, a portion of which are endangered, are traded through the Internet with unknown origin (Krigas et al. 2014). Such illegal and poorly regulated trade of flora and fauna over the Internet could thus undermine conservation efforts (Shirey et al. 2013).

The advantages of rapid spread of information and extensive connections through the Internet can, on the other hand, be utilized to raise awareness and increase the public's support for conservation issues. For instance, citizen science can be used to report the presence of invasive species, aiding in their control (Gallo and Waitt 2011). Environmental crime perpetrators can be exposed rapidly among web users and their crime can be publicly denounced in news and social media. For instance, under public pressure, three Vietnamese soldiers received military disciplinary action after posting pictures on Facebook in which they were torturing two critically endangered langurs (Pygathrix cinerea) (Nghiem et al. 2012). Also, the luring and subsequent shooting of the Southwest African lion (Panthera leo bleyenberghi) named Cecil in Zimbabwe sparked an international uproar following extensive news coverage and disclosure of the offenders (BBC 2015). This led to rapid effects: trophy hunting received widespread attention in social media, e.g., the hashtag "\#CecilTheLion" was used up to 250,000 times on Twitter (BBC 2015); awareness of trophy hunting and conservation efforts was heightened (Travers 2015); more than 1,300,000 signatures were obtained for AVAAZ's petition for the U.S. and European Union to ban the imports of trophies (https://secure.avaaz.org/en/ save africas lions loc/); and groups of airlines including Delta and United Airlines decided to ban transport of trophies of Africa's big five game animals (Graham 2015).

Shark fin consumption in Indonesia offers another example. In an effort to increase protection of sharks from over-hunting, Miss Riyanni Djangkaru, an Indonesian TV celebrity, created the "\#SaveSharks" campaign on Twitter. Since 2010, the campaign has gathered more than 230,000 followers who are encouraged to report restaurants and shops that sell shark products. Within a year, several supermarket chains (including Carrefour, Hypermart, Giant, and Hero) stopped selling shark fins. Another example was the online campaign petitioning to reject the Aceh spatial plan in Indonesia that drew more than 1.2 million signatures. Embassies took note and met with the Governor of Aceh and the EU Ambassador (https://secure.avaaz.org/en/ the plan to kill orangutans $\mathrm{cb} 1 /$ ?pv $=60 \& \mathrm{rc}=\mathrm{fb})$.

An increasingly affluent society and its social norms

Indirectly, but with a more profound influence, the telecoupling of information together with increasing affluence of the society in emerging economies represent a new key area of research for conservation (Fig. 2 where an increasingly affluent society represents agents influencing the telecoupling). On the one hand, consumption lifestyles are increasingly globalized toward diets with higher meat, sugar, and vegetable oil content (Kearney 2010). The increase in calorically high food consumption poses stronger pressures on the environment given the greater environmental footprints associated with food high in edible oil content (Lee et al. 2016). On the other hand, these large and affluent sections of the society have more access to information and social media platforms and may be more sensitive to environmental concerns (Guarin and Knorringa 2014). For instance, Indonesia is the world's largest user of Blackberry, second largest user of Facebook, and third largest user of Twitter, with Jakarta as the globally most active city on Twitter (Lipman 2012). As social media use continues to rise, there is a new opportunity to develop a more environmentally conscious society through conservation outreach, for example in China and Indonesia.

\section{DISCUSSION}

Our framework and examples on telecoupled trade and information flows show a pervasive duality of challenges and opportunities of telecoupling for biodiversity conservation. The same telecoupled forces that are able to fuel rapid tropical forest destruction can also motivate multinational agribusinesses to net zero deforestation. For better or for worse, telecoupled forces act with unprecedented speed, extent, and intensity leaving us little time to learn how to predict or manage them. Telecoupling can thus have pervasive influence on most conservation interventions. It may rapidly increase the pressure on land protection and management conservation interventions such as increasing deforestation pressure on protected areas (Nepstad et al. 2006) that could lead to protected area downgrading, downsizing, and degazettment (Symes et al. 2016). Telecoupling can also modify agricultural opportunity costs, compromising livelihood, economic and incentive-based conservation interventions. This is illustrated by payment for ecosystem services programs which may become unviable under increasing palm oil opportunity costs in Southeast Asia (Fisher et al. 2011). Telecoupling opens, however, opportunity windows chiefly via certification, 
consumers' pressures for environmental performance, corporate social responsibility, and social media.

Cecil's example demonstrates how social media can be useful for conservation. This is attained through netizens from various regions exerting pressure on policy makers as a united voice (WWF 2013, Turner 2014, Papworth et al. 2015). The explosive force of telecoupled information sharing via social media has however only produced isolated sparks contributing to conservation. We have only started to understand how Facebook, Twitter, and mobile apps can be used to create rapid campaigns to put pressure on environmental transgressions (Nghiem et al. 2012). We still need to know why sometimes a conservation problem gets a rapid outcry and other times it does not (Papworth et al 2015; Table 1).

Another key take home message is the high sensitivity of multinational agribusinesses and investors to being portrayed in a negative image because of environmental transgressions under telecoupling. Increasing the traceability of telecoupled impacts of trade by companies is thus a key leverage point to modify their behavior. Recent advances in traceability have been achieved by focusing on spatially explicit information on producer to consumer systems that are able to link companies to their distant ecological impacts (Godar et al. 2015).

Traceability is a way of enhancing the visibility of environmental actions, which is a key feature to change social norms and a leverage point to promote sustainable practices in companies (Nyborg et al. 2016). Similar principles seem to apply to financial markets where transparency and environmental performance shape the decisions of financial actors in a way that could help conserve biodiversity (Galaz et al. 2015).

Traceability, visibility, certification, and real time information provided to affluent consumers appear to be key opportunities to make use of telecoupling to promote biodiversity conservation. To this end, future work should focus on providing links between satellite images to land concessions, sustainability scorecards, and social media in real time to consumers (Nghiem and Carrasco 2016; Table 1). An example is the Sustainable Palm Oil Transparency Toolkit by the Zoological Society of London (https://www.spott.org/) that makes transparent the practices of oil palm companies and allows the public and stakeholders to assess their environmental claims.

At least as important as working on changing producers' behaviors is to change the consumption patterns of the increasingly affluent societies of large emerging and high-income economies. An additional research priority is thus to understand how social norms could be changed (Table 1). Experimental economics can provide key insights to conservation scientists on how expectations on the behaviors of others, fear of sanctions, and influential leaders can shape the evolution of social norms (Young 2015). For instance, people may adopt new behaviors if they are widespread or promoted by influential leaders and when the negative behavior is visible by others (Nyborg et al. 2016). This is illustrated by the aforementioned example of the Indonesian TV celebrity curbing shark fin consumption: a celebrity is a role model to people and shark fin selling and consumption is visible by others as it commonly takes place in supermarkets, restaurants, and banquets. A similar example is how smoking in public places, a highly visible behavior, suddenly stopped following policy interventions that caused a tipping point in multiple resourced nations (Nyborg et al. 2016). Visibility and the intervention of a celebrity may explain the successes of shark fin campaigns. Similar model roles for conservation have been played by Julia Roberts in the "Nature Is Speaking" videos by Conservation International and advertisements by basketball celebrity Yao Ming on discouraging shark fin consumption in China. Understanding policy leverage points to change social norms in increasingly affluent societies has thus a large potential for telecoupled conservation, yet how to do this remains poorly understood (Nyborg et al. 2016; Table 1).

Another key research gap to fill is the development of models able to identify potential spillover and feedback effects of telecoupling (Table 1), which can be detrimental for conservation interventions (Larrosa et al. 2016). Similarly, we need to understand how conservation interventions can create perverse telecoupled market feedbacks and spillovers (Lim et al. 2017). Although there are models that can link international trade to land use, there is a lack of models that can capture the potential spillover effects of telecoupling and how these may affect biodiversity, thus preventing managers from deriving management insights (an exception is the GLOBIOM model [Valin et al. 2013]). A combination of computable general equilibrium models that include trade and markets interactions (e.g., Hertel et al. 2014) and spatially explicit maps of biodiversity could help identify regions and species that will be threatened by telecoupled spillover effects and feedbacks.

Even though conservation interventions aimed at influencing telecoupled forces may provide effective ways to attain biodiversity conservation, these are unlikely to yield the desired objectives if they are not combined with on-the-ground conservation interventions. The integration of multiple scales and approaches, from global to local, will be necessary to materialize the potential incentives and changes generated by telecoupling. An example is how telecoupling may affect opportunity costs of protected areas, hunting, and encroachment pressures. Even if telecoupled forces cause a drop in agricultural prices and the demand for wildlife products is reduced, resource extractive activities may not change without further community engagement and provision of alternative livelihoods for local communities. This reinforces the idea that, although telecoupled conservation interventions are less explored and utilized, increasing the attention on them should not be done at the expense, but as a complement to, ongoing landscape-scale interventions. How to best attain this integration remains thus a key research priority (Table 1).

\section{CONCLUSION}

Telecoupling through trade and information poses both challenges and opportunities for conservation that are largely unknown. Use of certification schemes, increasing traceability, and information on environmental performance by companies appear fundamental to boost conservation by employing telecoupling forces. The other key conservation priority is to work on changing the social norms and environmental consciousness of increasingly affluent societies in countries like China, India, or Indonesia. Telecoupling is effectively changing the architecture of threats to biodiversity, creating conservation opportunities in 
distant supermarkets, corporation boardrooms, stock markets, and the Internet. Conservation practitioners thus need to learn to navigate in this rapidly evolving telecoupled system to seize the available opportunities and contribute to solve the conservation challenges of the 21 st century.

Responses to this article can be read online at: http://www.ecologyandsociety.org/issues/responses. php/9448

\section{Acknowledgments:}

L. R. C., J. C., F. L. M., and L. T. P. N. are thankful for research funding from a Tier 2 grant from the Ministry of Education of Singapore, MOE2015-T2-2-121. We thank Matt Linkie for helpful comments.

\section{LITERATURE CITED}

Adger, W. N., H. Eakin, and A. Winkels. 2009. Nested and teleconnected vulnerabilities to environmental change. Frontiers in Ecology and the Environment 7(3):150-157. http://dx.doi. org/10.1890/070148

Alacs, E., and A. Georges. 2008. Wildlife across our borders: a review of the illegal trade in Australia. Australian Journal of Forensic Sciences 40(2):147-160. http://dx. doi.org/10.1080/00450610802491382

Anderson, K. 2010. Globalization's effects on world agricultural trade, 1960-2050. Philosophical Transactions of the Royal Society B-Biological Sciences 365(1554):3007-3021.

Arshad, A., and D. Fogarty. 2016. Palm oil companies ditch landmark Indonesian 'zero deforestation' pact. The Straits Times, 1 July. [online] URL: http://www.straitstimes.com/asia/se-asia/ palm-oil-companies-ditch-landmark-indonesian-zero-deforestationpact

Auboin, M., M. Bacchetta, C. Beverelli, J. Hancock, C. Henn, M. Jansen, A. Keck, A. Maurer, C. Nee, A. Osnago, R. Piermartini, N. Rocha, R. Teh, N. Lamp, J. Nicol, J. Kategekwa, R. Lanz, and M. Roberts. 2014. World trade report 2014. Trade and development: recent trends and the role of the WTO. World Trade Organisation, Geneva, Switzerland.

BBC. 2015. How the internet descended on the man who killed Cecil the lion. BBC, 29 July. [online] URL: http://www.bbc.com/ news/blogs-trending-33694075

Bush, E. R., S. E. Baker, and D. W. Macdonald. 2014. Global trade in exotic pets 2006-2012. Conservation Biology 28 (3):663-676. http://dx.doi.org/10.1111/cobi.12240

Butler, R. A. 2015. Santander Bank cuts off APRIL due to deforestation. Mongabay, 24 February.

Carrasco, L. R., C. Larrosa, E. J. Milner-Gulland, and D. P. Edwards. 2014. A double-edged sword for tropical forests. Science 346(6205):38-40. http://dx.doi.org/10.1126/science.1256685

Carrete, M., and J. L. Tella. 2008. Wild-bird trade and exotic invasions: a new link of conservation concern? Frontiers in
Ecology and the Environment 6(4):207-211. http://dx.doi. org/10.1890/070075

Chang, J., W. S. Symes, F. Lim, and L. R. Carrasco. 2016. International trade causes large net economic losses in tropical countries via the destruction of ecosystem services. Ambio 45:387-397. http://dx.doi.org/10.1007/s13280-016-0768-7

Chaudhary, A., L. R. Carrasco, and T. Kastner. 2017. Linking national wood consumption with global biodiversity and ecosystem service losses. Science of The Total Environment 586:985-994. http://dx.doi.org/10.1016/j.scitotenv.2017.02.078

Chaudhary, A., and T. Kastner. 2016. Land use biodiversity impacts embodied in international food trade. Global Environmental Change 38:195-204. http://dx.doi.org/10.1016/j. gloenvcha.2016.03.013

Cook, D. C., L. R. Carrasco, D. R. Paini, and R. W. Fraser. 2011. Estimating the social welfare effects of New Zealand apple imports. Australian Journal of Agricultural and Resource Economics 55(4):599-620. http://dx.doi.org/10.1111/ j.1467-8489.2011.00558.x

Crona, B. I., T. M. Daw, W. Swartz, A. V. Norström, M. Nyström, M. Thyresson, C. Folke, J. Hentati-Sundberg, H. Österblom, L. Deutsch, and M. Troell. 2015. Masked, diluted and drowned out: how global seafood trade weakens signals from marine ecosystems. Fish and Fisheries 17:1175-1182. http://dx.doi. org/10.1111/faf.12109

Drake, J. M., and D. M. Lodge. 2004. Global hot spots of biological invasions: evaluating options for ballast-water management. Proceedings of the Royal Society B: Biological Sciences 271:575-655. http://dx.doi.org/10.1098/rspb.2003.2629

Eakin, H. C., and M. B. Wehbe. 2009. Linking local vulnerability to system sustainability in a resilience framework: two cases from Latin America. Climatic Change 93(3-4):355-377. http://dx.doi. org/10.1007/s10584-008-9514-X

Fisher, B., D. P. Edwards, X. Giam, and D. S. Wilcove. 2011. The high costs of conserving Southeast Asia's lowland rainforests. Frontiers in Ecology and the Environment 9:329-334. http://dx.doi. org/10.1890/100079

Fitzherbert, E. B., M. J. Struebig, A. Morel, F. Danielsen, C. A. Brühl, P. F. Donald, and B. Phalan. 2008. How will oil palm expansion affect biodiversity? Trends in Ecology \& Evolution 23 (10):538-545. http://dx.doi.org/10.1016/j.tree.2008.06.012

Food and Agriculture Organization of the United Nations (FAO). 2016. FAOSTAT. FAO, Rome, Italy. [online] URL: http://faostat. fao.org/site/342/default.aspx

Galaz, V., J. Gars, F. Moberg, B. Nykvist, and C. Repinski. 2015. Why ecologists should care about financial markets. Trends in Ecology \& Evolution 30(10):571-580. http://dx.doi.org/10.1016/j. tree.2015.06.015

Gallo, T., and D. Waitt. 2011. Creating a successful citizen science model to detect and report invasive species. BioScience 61 (6):459-465. http://dx.doi.org/10.1525/bio.2011.61.6.8

Godar, J., U. M. Persson, E. J. Tizado, and P. Meyfroidt. 2015. Towards more accurate and policy relevant footprint analyses: 
tracing fine-scale socio-environmental impacts of production to consumption. Ecological Economics 112:25-35. http://dx.doi. org/10.1016/j.ecolecon.2015.02.003

Godfray, H. C. J., J. R. Beddington, I. R. Crute, L. Haddad, D. Lawrence, J. F. Muir, J. Pretty, S. Robinson, S. M. Thomas, and C. Toulmin. 2010. Food security: the challenge of feeding 9 billion people. Science 327(5967):812-818. http://dx.doi.org/10.1126/ science. 1185383

Graham, A. H. 2015. After killing of Cecil the lion, Delta joins airline ban on game trophies. The New York Times, 3 August.

Graham-Rowe, D. 2011. Biodiversity: endangered and in demand. Nature 480(7378):S101-S103. http://dx.doi.

org/10.1038/480S101a

Guarin, A., and P. Knorringa. 2014. New middle-class consumers in rising powers: responsible consumption and private standards. Oxford Development Studies 42(2):151-171. http://dx.doi. org/10.1080/13600818.2013.864757

Harris, J. B. C., M. W. Tingley, F. Hua, D. L. Yong, J. M. Adeney, T. M. Lee, W. Marthy, D. M. Prawiradilaga, C. H. Sekercioglu, N. Winarni, Suyadi, N. Winarni, and D. S. Wilcove. 2016. Measuring the impact of the pet trade on Indonesian birds. Conservation Biology 31:394-405. http://dx.doi.org/10.1111/ cobi. 12729

Hertel, T. W., N. Ramankutty, and U. L. C. Baldos. 2014. Global market integration increases likelihood that a future African Green Revolution could increase crop land use and $\mathrm{CO}_{2}$ emissions. Proceedings of the National Academy of Sciences of the USA 111(38):13799-13804. http://dx.doi.org/10.1073/pnas.1403543111

Hovland, K. M. 2015. Norway oil fund excludes companies on environment risks. The Wall Street Journal, 17 August.

Hulme, P. E. 2009. Trade, transport and trouble: managing invasive species pathways in an era of globalization. Journal of Applied Ecology 46(1):10-18. http://dx.doi.org/10.1111/ j.1365-2664.2008.01600.x

Kearney, J. 2010. Food consumption trends and drivers. Philosophical Transactions of the Royal Society B: Biological Sciences 365(1554):2793-2807. http://dx.doi.org/10.1098/rstb.2010.0149

Kitzes, J., E. Berlow, E. Conlisk, K. Erb, K. Iha, N. Martinez, E. A. Newman, C. Plutzar, A. B. Smith, and J. Harte. 2016. Consumption-based conservation targeting: linking biodiversity loss to upstream demand through a global wildlife footprint. Conservation Letters. http://dx.doi.org/10.1111/con4.12321

Krigas, N., V. Menteli, and D. Vokou. 2014. The electronic trade in Greek endemic plants: biodiversity, commercial and legal aspects. Economic Botany 68(1):85-95. http://dx.doi.org/10.1007/ $\underline{\text { s12231-014-9264-9 }}$

Lambin, E. F., and P. Meyfroidt. 2011. Global land use change, economic globalization, and the looming land scarcity. Proceedings of the National Academy of Sciences of the USA 108 (9):3465-3472. http://dx.doi.org/10.1073/pnas.1100480108

Larrosa, C., L. R. Carrasco, and E. J. Milner-Gulland. 2016. Unintended feedbacks: challenges and opportunities for improving conservation effectiveness. Conservation Letters 9 (5):316-326. http://dx.doi.org/10.1111/conl.12240
Lee, J. S. H., L. P. Koh, and D. S. Wilcove. 2016. Junking tropical forests for junk food? Frontiers in Ecology and the Environment 14(7):355-356. http://dx.doi.org/10.1002/fee.1300

Lenzen, M., D. Moran, K. Kanemoto, B. Foran, L. Lobefaro, and A. Geschke. 2012. International trade drives biodiversity threats in developing nations. Nature 486(7401):109-112. http:// dx.doi.org/10.1038/nature11145

Lim, F. K. S., L. R. Carrasco, J. McHardy, and D. P. Edwards. 2017. Perverse market outcomes from biodiversity conservation interventions. Conservation Letters. http://dx.doi.org/10.1111/ conl.12332

Lipman, V. 2012. The world's most active Twitter city? You won't guess it. Forbes, 30 December. [online] URL: http://www.forbes. com/sites/victorlipman/2012/12/30/the-worlds-most-active-twittercity-you-wont-guess-it/\#483782cf6343

Liu, J., V. Hull, M. Batistella, R. DeFries, T. Dietz, F. Fu, T. W. Hertel, R. C. Izaurralde, E. F. Lambin, S. Li, L. A. Martinelli, W. J. McConnell, E. F. Moran, R. Naylor, Z. Ouyang, K. R. Polenske, A. Reenberg, G. de Miranda Rocha, C. S. Simmons, P. H. Verburg, P. M. Vitousek, F. Zhang, and C. Zhu. 2013. Framing sustainability in a telecoupled world. Ecology and Society 18 (2):26. http://dx.doi.org/10.5751/ES-05873-180226

Liu, J., V. Hull, J. Luo, W. Yang, W. Liu, A. Viña, C. Vogt, Z. Xu, H. Yang, J. Zhang, L. An, X. Chen, S. Li, Z. Ouyang, W. Xu and H. Zhang. 2015a. Multiple telecouplings and their complex interrelationships. Ecology and Society 20(3):44. http://dx.doi. org/10.5751/ES-07868-200344

Liu, J., H. Mooney, V. Hull, S. J. Davis, J. Gaskell, T. Hertel, J. Lubchenco, K. C. Seto, P. Gleick, C. Kremen, and S. Li. $2015 b$. Systems integration for global sustainability. Science 347 (6225):1258832. http://dx.doi.org/10.1126/science.1258832

Meyfroidt, P., and E. F. Lambin. 2009. Forest transition in Vietnam and displacement of deforestation abroad. Proceedings of the National Academy of Sciences of the USA 106 (38):16139-16144. http://dx.doi.org/10.1073/pnas.0904942106

Moran, D., and K. Kanemoto. 2017. Identifying species threat hotspots from global supply chains. Nature Ecology \& Evolution 1:0023.

Nepstad, D. C., C. M. Stickler, and O. T. Almeida. 2006. Globalization of the Amazon soy and beef industries: opportunities for conservation. Conservation Biology 20 (6):1595-1603. http://dx.doi.org/10.1111/j.1523-1739.2006.00510. $\underline{\mathrm{x}}$

Nghiem, L. T. P., E. L. Webb, and L. R. Carrasco. 2012. Saving Vietnam's wildlife through social media. Science 338 (6104):192-193. http://dx.doi.org/10.1126/science.338.6104.192b

Nghiem, L. T. P., T. Soliman, D. C. J. Yeo, H. T. W. Tan, T. A. Evans, J. D. Mumford, R. P. Keller, R. H. A. Baker, R. T. Corlett, and L. R. Carrasco. 2013. Economic and environmental impacts of harmful non-indigenous species in Southeast Asia. PLoS ONE 8(8):e71255. http://dx.doi.org/10.1371/journal.pone.0071255

Nghiem, T. P. L., and L. R. Carrasco. 2016. Mobile applications to link sustainable consumption with impacts on the environment 
and biodiversity. BioScience 66:384-392. http://dx.doi.org/10.1093/ biosci/biw016

Nishijima, S., T. Furukawa, T. Kadoya, F. Ishihama, T. Kastner, H. Matsuda, and N. Kaneko. 2016. Evaluating the impacts of wood production and trade on bird extinction risks. Ecological Indicators 71:368-376. http://dx.doi.org/10.1016/j.ecolind.2016.07.008

Nyborg, K., J. M. Anderies, A. Dannenberg, T. Lindahl, C. Schill, M. Schlüter, W. N. Adger, K. J. Arrow, S. Barrett, S. Carpenter, F. S. Chapin III, A.-S. Crépin, G. Daily, P. Ehrlich, C. Folke, W. Jager, N. Kautsky, S. A. Levin, O. J. Madsen, S. Polasky, M. Scheffer, B. Walker, E. U. Weber, J. Wilen, A. Xepapadeas, and A. de Zeeuw. 2016. Social norms as solutions. Science 354 (6308):42-43. http://dx.doi.org/10.1126/science.aaf8317

Organisation for Economic Co-operation and DevelopmentFood and Agriculture Organization of the United Nations (OECD-FAO). 2014. OECD-FAO agricultural outlook 2014. OECD Publishing, Paris, France. http://dx.doi.org/10.1787/ agr outlook-2014-en

Papworth, S. K., T. P. L. Nghiem, D. Chimalakonda, M. R. C. Posa, L. S. Wijedasa, D. Bickford, and L. R. Carrasco. 2015. Quantifying the role of online news in linking conservation research to Facebook and Twitter. Conservation Biology 29 (3):825-833. http://dx.doi.org/10.1111/cobi.12455

Pirard, R., S. Gnych, P. Pacheco, and S. Lawry. 2015. Zerodeforestation commitments in Indonesia: governance challenges. Center for International Forestry Research (CIFOR), Bogor, Indonesia.

Rueda, X., and E. F. Lambin. 2013. Linking globalization to local land uses: how eco-consumers and gourmands are changing the Colombian coffee landscapes. World Development 41:286-301. http://dx.doi.org/10.1016/j.worlddev.2012.05.018

Shirey, P. D., B. N. Kunycky, D. T. Chaloner, M. A. Brueseke, and G. A. Lamberti. 2013. Commercial trade of federally listed threatened and endangered plants in the United States. Conservation Letters 6(5):300-316. http://dx.doi.org/10.1111/ conl.12031

Srinivasan, U. T., S. P. Carey, E. Hallstein, P. A. T. Higgins, A. C. Kerr, L. E. Koteen, A. B. Smith, R. Watson, J. Harte, and R. B. Norgaard. 2008. The debt of nations and the distribution of ecological impacts from human activities. Proceedings of the National Academy of Sciences of the USA 105(5):1768-1773. http://dx.doi.org/10.1073/pnas.0709562104

Sunderlin, W. D. 1999. Between danger and opportunity: Indonesia and forests in an era of economic crisis and political change. Society \& Natural Resources 12(6):559-570. http://dx.doi. org/10.1080/089419299279443

Symes, W. S., M. Rao, M. B. Mascia, and L. R. Carrasco. 2016. Why do we lose protected areas? Factors influencing protected area downgrading, downsizing and degazettement in the tropics and subtropics. Global Change Biology 22(2):656-665. http://dx. doi.org/10.1111/gcb.13089

Tayleur, C., A. Balmford, G. M. Buchanan, S. H. M. Butchart, H. Ducharme, R. E. Green, J. C. Milder, F. J. Sanderson, D. H.
L. Thomas, J. Vickery, and B. Phalan. 2016. Global coverage of agricultural sustainability standards, and their role in conserving biodiversity. Conservation Letters. http://dx.doi.org/10.1111/ conl.12314

The World Bank. 2015. World development indicators online. World Bank, Washington, D.C., USA.

Tilman, D., C. Balzer, J. Hill, and B. L. Befort. 2011. Global food demand and the sustainable intensification of agriculture. Proceedings of the National Academy of Sciences of the USA 108 (50):20260-20264. http://dx.doi.org/10.1073/pnas.1116437108

Travers, W. 2015. A major misfire. New Scientist 227(3033):22-23. http://dx.doi.org/10.1016/S0262-4079(15)30928-3

Turner, J. 2014. Today LEGO dumped Shell - Here's why it matters to us all. Greenpeace International, 9 October. [online] URL: http://www.greenpeace.org/international/en/news/Blogs/makingwaves/ save-the-arctic-lego-dumps-shell/blog/50926/

UN. 2015. The world population prospects: 2015 revision. United Nations, Department of Economic and Social Affairs, New York, New York, USA. [online] URL: http://www.un.org/en/ development/desa/publications/world-population-prospects-2015revision.html

Valin, H., P. Havlík, N. Forsell, S. Frank, A. Mosnier, D. Peters, C. Hamelinck, M. Spöttle, and M. van den Berg. 2013. Description of the GLOBIOM (IIASA) model and comparison with the MIRAGE-BioF (IFPRI) Model. Crops 8:3.1.

Viña, A., W. J. McConnell, H. Yang, Z. Xu, and J. Liu. 2016. Effects of conservation policy on China's forest recovery. Science Advances 2(3):e1500965. http://dx.doi.org/10.1126/sciadv.1500965

Wilcove, D. S., and L. P. Koh. 2010. Addressing the threats to biodiversity from oil-palm agriculture. Biodiversity and Conservation 19(4):999-1007. http://dx.doi.org/10.1007/s10531-009-9760$\underline{\mathrm{X}}$

Wiles, G. J., J. Bart, R. E. Beck Jr, and C. F. Aguon. 2003. Impacts of the brown tree snake: patterns of decline and species persistence in Guam's avifauna. Conservation Biology 17 (5):1350-1360. http://dx.doi.org/10.1046/j.1523-1739.2003.01526. $\underline{x}$

World Wildlife Fund (WWF). 2013. Thai prime minister announces end to ivory trade. WWF, Washington, D.C., USA.

World Wildlife Fund (WWF). 2016. Palm oil buyers scorecard 2016. Measuring the sustainability of palm oil buyers. WWF, Washington, D.C., USA. [online] URL: http://palmoilscorecard. panda.org/.

Young, H. P. 2015. The evolution of social norms. Annual Review of Economics 7(1):359-387. http://dx.doi.org/10.1146/annureveconomics-080614-115322 